\title{
Alloantigen expression on non-hematopoietic cells reduces graft-versus-leukemia effects in mice
}

\author{
Shoji Asakura, ${ }^{1}$ Daigo Hashimoto, ${ }^{1,2}$ Shuichiro Takashima, ${ }^{3}$ Haruko Sugiyama, ${ }^{1}$ Yoshinobu Maeda, ${ }^{1}$ \\ Koichi Akashi, ${ }^{2,3}$ Mitsune Tanimoto, ${ }^{1}$ and Takanori Teshima ${ }^{2}$ \\ ${ }^{1}$ Biopathological Science, Okayama University Graduate School of Medicine and Dentistry, Okayama, Japan. ${ }^{2}$ Center for Cellular and Molecular Medicine and \\ ${ }^{3}$ Department of Medicine and Biosystemic Science, Kyushu University Graduate School of Science, Fukuoka, Japan.
}

\begin{abstract}
Allogeneic hematopoietic stem cell transplantation (HSCT) is used effectively to treat a number of hematological malignancies. Its beneficial effects rely on donor-derived T cell-targeted leukemic cells, the so-called graft-versus-leukemia (GVL) effect. Induction of GVL is usually associated with concomitant development of graft-versus-host disease (GVHD), a major complication of allogeneic HSCT. The T cells that mediate GVL and GVHD are activated by alloantigen presented on host antigen-presenting cells of hematopoietic origin, and it is not well understood how alloantigen expression on non-hematopoietic cells affects GVL activity. Here we show, in mouse models of MHC-matched, minor histocompatibility antigen-mismatched bone marrow transplantation, that alloantigen expression on host epithelium drives donor $\mathrm{T}$ cells into apoptosis and dysfunction during GVHD, resulting in a loss of GVL activity. During GVHD, programmed death-1 (PD-1) and PD ligand-1 (PD-L1), molecules implicated in inducing $T$ cell exhaustion, were upregulated on activated $T$ cells and the target tissue, respectively, suggesting that the $T$ cell defects driven by host epithelial alloantigen expression might be mediated by the PD-1/PD-L1 pathway. Consistent with this, blockade of PD-1/PD-L1 interactions partially restored $\mathrm{T}$ cell effector functions and improved GVL. These results elucidate a previously unrecognized significance of alloantigen expression on non-hematopoietic cells in GVL and suggest that separation of GVL from GVHD for more effective HSCT may be possible in human patients.
\end{abstract}

\section{Introduction}

Donor immunity in allogeneic hematopoietic stem cell transplantation (HSCT) harnesses beneficial graft-versus-leukemia (GVL) effects; therefore, allogeneic HSCT represents a very potent form of immunotherapy for hematological malignancies $(1,2)$. Induction of GVL is usually associated with the development of graftversus-host disease (GVHD), which is a major complication after allogeneic HSCT. T cell depletion of the donor inocula prevents GVHD and leads to a loss of the GVL effect (3-5). Both GVL and GVHD are mediated by donor $T$ cells, which recognize alloantigens presented on host APCs $(6,7)$. Donor CTLs and inflammatory cytokines are major effectors of GVHD, whereas CTLs are primarily responsible for $\operatorname{GVL}(8,9)$. In patients with advanced-stage leukemia and lymphoma, relapse is still a major cause of mortality after allogeneic HSCT even after the development of severe GVHD. Thus, improvements in our understanding of the pathophysiology of GVHD and GVL are urgently needed to develop more effective therapies for malignant diseases.

Alloantigens are expressed on the three major components in HSCT recipients in the context of GVHD and GVL: hematopoietically derived APCs, GVHD target epithelium, and leukemia cells. Several studies have shown that host APCs are crucial for the induction of both GVHD and GVL $(6,7,9-11)$. Alloantigen expression on epithelium is also critical for the induction of GVHD in MHCmatched, minor histocompatibility antigen-mismatched (mHAmismatched) models of bone marrow transplantation (BMT) (10), but GVHD can occur in the absence of alloantigen expression on

Conflict of interest: The authors have declared that no conflict of interest. Citation for this article: J Clin Invest. 2010;120(7):2370-2378. doi:10.1172/JCI39165 epithelium in MHC-mismatched models of BMT (9). However, the effect of alloantigen expression on non-hematopoietic cells such as the epithelium in GVL is not well defined. In this study, we addressed this important issue in mHA-mismatched models of BMT.

\section{Results}

Alloantigen expression on host non-bematopoietic cells augments acute $G V H D$ but reduces GVL effects. We generated BM chimeric mice that express alloantigens on APCs, which are essential for the induction of both GVHD and GVL $(6,7,12)$. BM chimeras were created by reconstituting lethally irradiated C3H.Sw $\left(\mathrm{C} 3: \mathrm{H}-2^{\mathrm{b}}\right)$ mice with $5 \times 10^{6} \mathrm{~T}$ cell-depleted (TCD) BM cells isolated from C57BL/6 (B6, $\left.\mathrm{H}-2^{\mathrm{b}}\right)$ mice that differ from C3 mice at multiple mHAs $([\mathrm{B} 6 \rightarrow \mathrm{C} 3]$ chimeras). Control chimeras, [B6 $\rightarrow$ B6], were identically created. Four months later, donor repopulation of hematopoiesis was confirmed by flow cytometry as shown previously $(6,9,12)$. Thus, $[\mathrm{B} 6 \rightarrow \mathrm{C} 3]$ chimeric mice expressed B6-derived mHAs on hematopoietically derived APCs but not on non-hematopoietic target cells. In contrast, [B6 $\rightarrow$ B6] mice expressed B6-derived mHAs on both APCs and target epithelium. These chimeras were used as $\mathrm{BMT}$ recipients; they were reirradiated and injected with $5 \times 10^{6}$ TCD BM cells alone or with various doses of $\mathrm{CD}^{+} \mathrm{T}$ cells from $\mathrm{C} 3$ donors. After BMT, GVHD mortality was higher in [B6 $\rightarrow$ B6] mice than in $[\mathrm{B} 6 \rightarrow \mathrm{C} 3]$ mice (Figure 1A). Clinical GVHD scores (13) in surviving animals were also higher in $[\mathrm{B} 6 \rightarrow \mathrm{B} 6]$ mice than in $[\mathrm{B} 6 \rightarrow \mathrm{C} 3]$ mice (Figure 1B). Mortality and morbidity from GVHD in $[\mathrm{B} 6 \rightarrow \mathrm{C} 3]$ mice were almost equivalent to those in $[\mathrm{B} 6 \rightarrow \mathrm{B} 6]$ mice given a 1-log lower $\mathrm{T}$ cell dose. This finding confirmed the previous observation of a lack of alloantigen expression on host epithelium significantly reducing GVHD across mHA disparity (10). We 

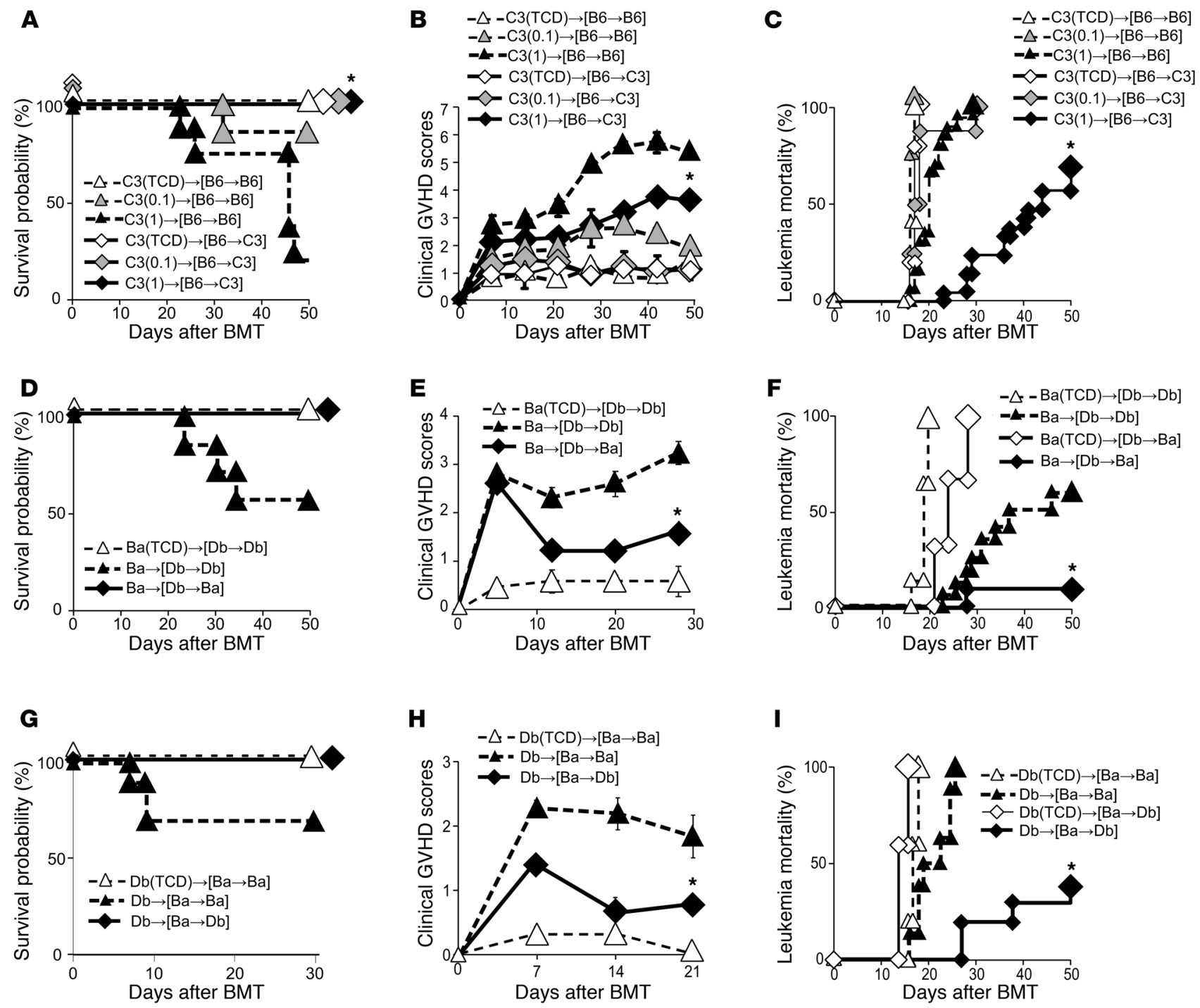

Figure 1

Alloantigen expression on host non-hematopoietic cells augments acute GVHD but reduces GVL effects. (A-C) [B6 $\rightarrow$ C3] (diamonds) and $[\mathrm{B} 6 \rightarrow \mathrm{B} 6]$ chimeras (triangles) were created by reconstituting lethally irradiated C3 and B6 mice with $5 \times 10^{6}$ TCD BM cells from B6 mice. Four months later, the chimeras were reirradiated and injected with $5 \times 10^{6}$ TCD BM cells alone (open symbols) or with $1 \times 10^{6}$ (black symbols) or $0.1 \times 10^{6}$ (gray symbols) CD8+ T cells from C3 donors (as indicated in parentheses $\left.\times 10^{6}\right)$. Survival $($ A) and clinical GVHD scores $(B)$ after BMT ( $n=3-8$ /group). (C) Leukemia mortality after BMT in chimeras injected with EL4 cells ( $n=5-21 /$ group). Data from 3 similar experiments were combined. (D-F) $[\mathrm{Db} \rightarrow \mathrm{Ba}]$ (diamonds) and [Db $\rightarrow \mathrm{Db}$ ] (triangles) chimeras were reirradiated and injected with TCD BM alone (open symbols) or with $2 \times 10^{6} \mathrm{~T}$ cells from Ba donors (filled symbols). Survival (D) and clinical GVHD scores (E) after BMT from a representative experiment of 2 similar experiments ( $n=4-7 /$ group). (F) Leukemia mortality after BMT in mice injected with P815 cells. Data from 2 similar experiments were combined ( $n=6-18 /$ group). (G-I) $[\mathrm{Ba} \rightarrow \mathrm{Db}]$ (diamonds) and $\left[\mathrm{Ba} \rightarrow \mathrm{Ba}\right.$ ] (triangles) chimeras were similarly transplanted with $5 \times 10^{6} \mathrm{TCD}$ BM cells alone (open symbols) or with $2 \times 10^{6} \mathrm{~T}$ cells from Db donors (filled symbols). Survival (G) and clinical scores $(\mathbf{H})$ after BMT ( $\left.n=3-10 / g r o u p\right)$. (I) Leukemia mortality after BMT in chimeras injected with A20 cells ( $n=5-10 / g r o u p)$. Data from 2 similar experiments were combined. Clinical scores are shown as the mean \pm SEM. ${ }^{*} P<0.05$ compared with allogeneic controls.

then tested the effect of alloantigen expression on GVHD target epithelium on GVL effects. These chimeric mice were transplanted as described above together with 2,500 B6-derived EL4 cells as a model of residual leukemia after BMT. As expected, $100 \%$ of both types of chimeric mice that received TCD BM cells died from leukemia by day +20 after BMT (Figure 1C), whereas leukemia-free survival was significantly prolonged in mice that received donor T cells, demonstrating a significant GVL effect. However, this GVL effect was not potent in $[\mathrm{B} 6 \rightarrow \mathrm{B} 6]$ mice, and all mice subsequently died from leukemia. Surprisingly, leukemia mortality was significantly lower in $[\mathrm{B} 6 \rightarrow \mathrm{C} 3]$ mice that did not express alloantigens on their non-hematopoietic cells (62\% vs. $100 \% ; P<0.05)$. GVL effects in $[\mathrm{B} 6 \rightarrow \mathrm{B} 6]$ mice appeared to be almost equivalent to those in $[\mathrm{B} 6 \rightarrow \mathrm{C} 3]$ mice given a $1-\log$ lower $\mathrm{T}$ cell dose.

We further confirmed these observations in a different strain combination: BALB/c (Ba, H-2 $\left.{ }^{\mathrm{d}}\right)$ and DBA/2 (Db, H-2d) mice that 

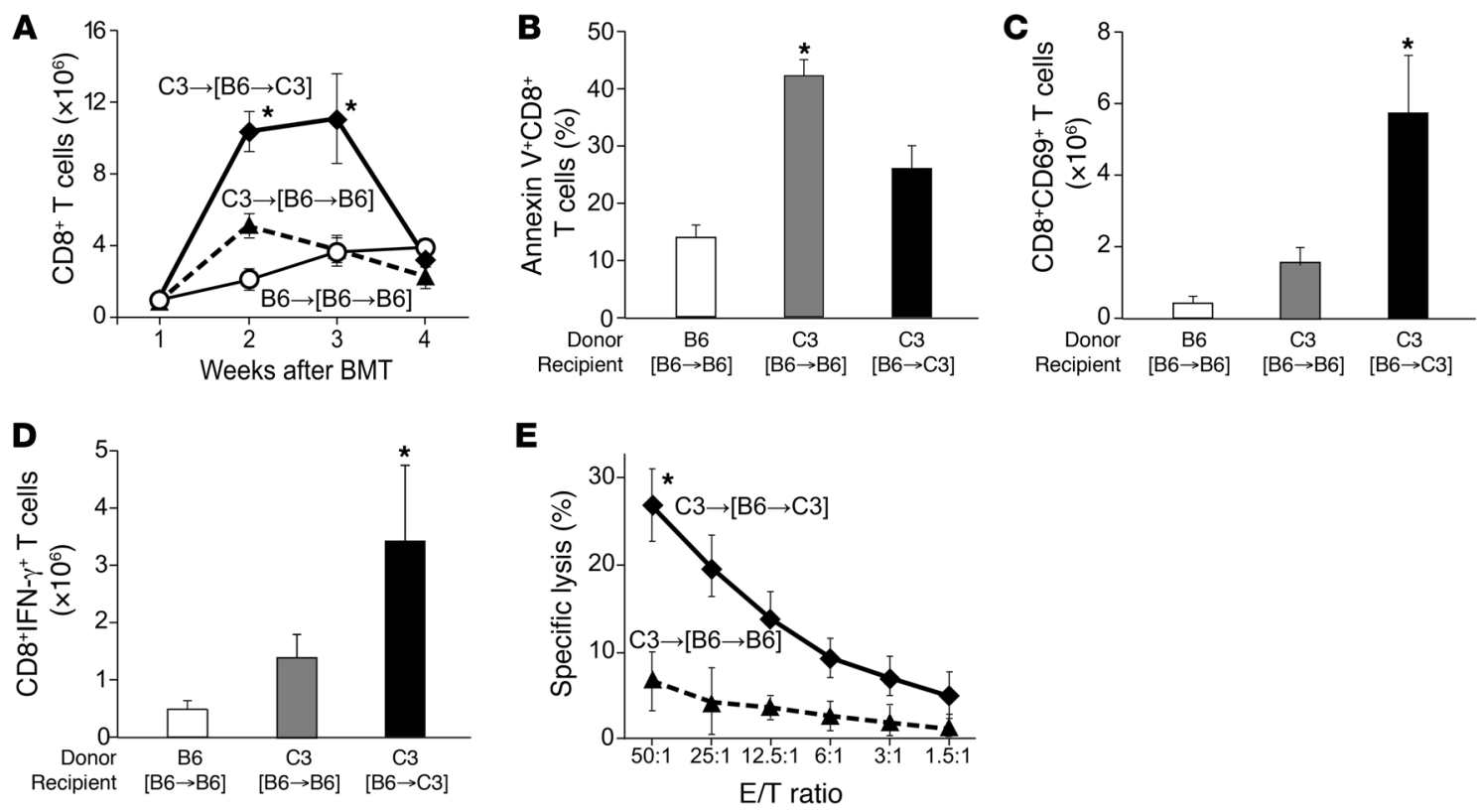

\section{Figure 2}

Alloantigen expression on host non-hematopoietic cells enhances the apoptosis and dysfunction of alloreactive T cells. [B6 $\rightarrow$ C3] (diamonds and black bars) and [B6 $\rightarrow \mathrm{B} 6]$ (triangles and gray bars) chimeras were transplanted as indicated in the legend for Figure 1. Syngeneic controls were $[B 6 \rightarrow B 6]$ recipients of B6.Ly5.1 (CD45.1+) cells (open circles and white bars). (A) Numbers of donor CD8+ ${ }^{+}$cells in spleens. (B) Frequencies of annexin $\mathrm{V}^{+}$donor CD8 ${ }^{+} \mathrm{T}$ cells. (C) Numbers of annexin $\mathrm{V}^{-}$donor CD69+CD8 ${ }^{+} \mathrm{T}$ cells. (D) Numbers of annexin $\mathrm{V}^{-}$IFN- $\gamma$-producing donor CD8 ${ }^{+}$T cells. (E) CTL activity against EL4. (B-E) Analysis was performed 14 days after BMT ( $\left.n=3-8 / g r o u p\right)$. Representative data from 1 of the experiments are shown as the mean $\pm \mathrm{SD}$. ${ }^{*} P<0.05$ compared with allogeneic controls.

differed at multiple mHAs from each other. $[\mathrm{Db} \rightarrow \mathrm{Ba}]$ and control $[\mathrm{Db} \rightarrow \mathrm{Db}]$ chimeras were lethally reirradiated and injected with $5 \times 10^{6}$ TCD BM cells alone or with $2 \times 10^{6} \mathrm{Ba}$ T cells. Mortality (Figure 1D, $P=0.08$ ) and morbidity from GVHD (Figure 1E, $P<0.05)$ were higher in $[\mathrm{Db} \rightarrow \mathrm{Db}]$ mice than in $[\mathrm{Db} \rightarrow \mathrm{Ba}]$ mice. When cells were transplanted together with 2,000 Db-derived P815 cells, leukemia mortality was significantly lower in $[\mathrm{Db} \rightarrow \mathrm{Ba}]$ mice than in $[\mathrm{Db} \rightarrow \mathrm{Db}]$ mice $(10 \%$ vs. $60 \% ; P<0.05)$ (Figure $1 \mathrm{~F})$.

Similar results were obtained when $[\mathrm{Ba} \rightarrow \mathrm{Db}]$ and control $[\mathrm{Ba} \rightarrow \mathrm{Ba}]$ chimeras were transplanted with $5 \times 10^{6}$ TCD BM cells with or without $2 \times 10^{6} \mathrm{Db}$ T cells. In $[\mathrm{Ba} \rightarrow \mathrm{Db}]$ recipients, in which nonhematopoietic cells do not express alloantigens, mortality (Figure $1 \mathrm{G}, P=0.08$ ) and morbidity of GVHD (Figure $1 \mathrm{H}, P<0.05$ ) were lower, but GVL effects against Ba-derived A20 lymphoma cells were significantly more potent as compared with $[\mathrm{Ba} \rightarrow \mathrm{Ba}]$ controls (leukemia mortality: $30 \%$ vs. $100 \%$; $P$ < 0.05) (Figure 1I). Taken together, these results demonstrate that GVHD is decreased but GVL activity is enhanced in the absence of alloantigen expression on non-hematopoietic cells.

Alloantigen expression on non-hematopoietic cells enhances apoptosis and dysfunction of alloreactive T cells. GVHD and GVL in the C3 and B6 strain combination is dependent on donor $\mathrm{CD}^{+} \mathrm{T}$ cells $(12,14)$. To elucidate the mechanisms responsible for the enhancement of the GVL effect in [B6 $\rightarrow$ C3] chimeric mice, which lack alloantigen expression on non-hematopoietic cells, the kinetics of donor $\mathrm{CD}^{+} \mathrm{T}$ cell expansion and activation were evaluated after BMT. Expansion of donor $\mathrm{CD}^{+} \mathrm{T}$ cells identified as $\mathrm{CD} 5.1^{+} \mathrm{CD}^{+}$cells peaked on day +14 in the spleens of allogeneic $[\mathrm{B} 6 \rightarrow \mathrm{B} 6]$ recipients and decreased thereafter (Figure $2 \mathrm{~A}$ ), as previously shown in this model (15). CD8 expansion was significantly greater in [B6 $\rightarrow \mathrm{C} 3]$ mice than in $[\mathrm{B} 6 \rightarrow \mathrm{B} 6]$ mice on days +14 and +21 . We next assessed donor $\mathrm{T}$ cell apoptosis as a determinant of the kinetics of $\mathrm{T}$ cell expansion. Frequencies of annexin $\mathrm{V}^{+}$apoptotic donor $\mathrm{CD}^{+} \mathrm{T}$ cells were significantly greater in the spleen of $[\mathrm{B} 6 \rightarrow \mathrm{B} 6]$ mice as compared with that of $[\mathrm{B} 6 \rightarrow \mathrm{C} 3]$ mice on day +14 (Figure 2B). Notably, surviving donor $\mathrm{CD}^{+} \mathrm{T}$ cells were significantly less activated in $[\mathrm{B} 6 \rightarrow \mathrm{B} 6]$ mice than in $[\mathrm{B} 6 \rightarrow \mathrm{C} 3]$ mice when evaluated based on the expression of CD69 (Figure 2C) and intracellular IFN- $\gamma$ (Figure $2 \mathrm{D}$ ) on annexin $\mathrm{V}^{-}$donor $\mathrm{CD}^{+} \mathrm{T}$ cells. We next evaluated CTL activity in donor $\mathrm{T}$ cells isolated from the spleen on day +14 after BMT. CTL activity against EL4 targets was significantly reduced in the splenocytes of [B6 $\rightarrow$ B6] mice as compared with [B6 $\rightarrow \mathrm{C} 3]$ mice (Figure 2E). These results suggest that alloantigen expression on non-hematopoietic cells induces apoptosis and dysfunction of alloreactive T cells.

Absence of alloantigen expression on host non-hematopoietic cells restores GVL effects. Self-recognition in the periphery facilitates the reactivity of mature T cells to foreign antigens (16). Therefore, it is possible that the expression of syngeneic MHC molecules and not the absence of alloantigens on non-hematopoietic cells may be responsible for the enhancement of the GVL effect in [B6 $\rightarrow \mathrm{C} 3]$ chimeras. This possibility was tested in B6-background $\beta_{2} \mathrm{~m}^{-/-}$mice. [B6 $\rightarrow$ $\beta_{2} \mathrm{~m}^{-/-}$chimeras lacking functional MHC class I molecules on non-hematopoietic cells did not develop GVHD after transplantation with $\mathrm{CD}^{+} \mathrm{T}$ cells from $\mathrm{C} 3$ donors, as shown previously (17) (Figure 3A). In these mice, however, leukemia mortality was significantly delayed even in the absence of GVHD as compared with $[\mathrm{B} 6 \rightarrow \mathrm{B} 6]$ recipients (Figure $3 \mathrm{~B}, P<0.05$ ). The expansion and $\mathrm{CTL}$ activity of donor $\mathrm{CD}^{+} \mathrm{T}$ cells was significantly greater in $[\mathrm{B} 6 \rightarrow$ $\left.\beta_{2} \mathrm{~m}^{-/}\right]$recipients than in $[\mathrm{B} 6 \rightarrow \mathrm{B} 6]$ recipients (Figure $3, \mathrm{C}$ and $\mathrm{D}$ ). 
A

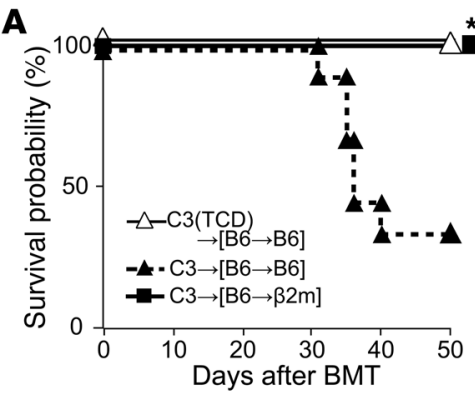

\section{C}

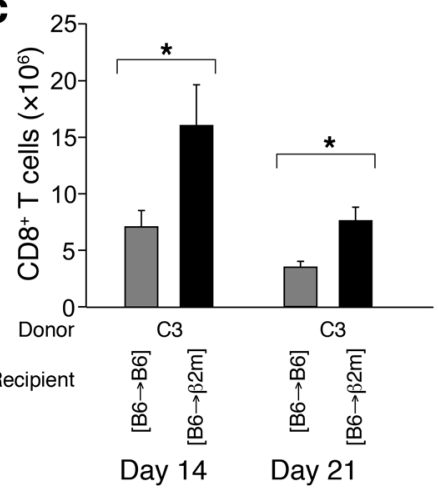

\section{B}
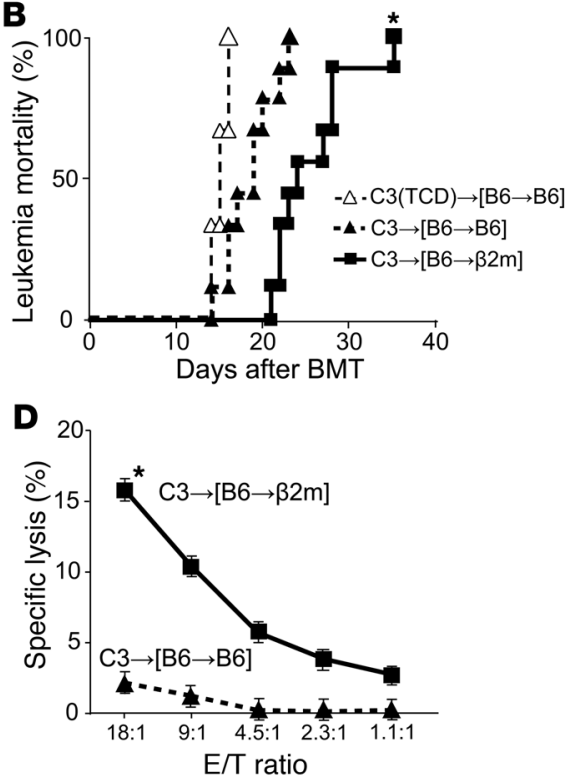

\section{Figure 3}

Absence of alloantigen expression on host nonhematopoietic cells restores GVL effects. [B6 $\rightarrow$ B6] (triangles) and $\left[\mathrm{B} 6 \rightarrow \beta 2 \mathrm{~m}^{-/-}\right]$(squares) mice were reirradiated and injected with $5 \times 10^{6} \mathrm{TCD}$ BM cells alone (open symbols) or with $1 \times 10^{6} \mathrm{CD}^{+} \mathrm{T}$ cells from C3 donors (filled symbols). (A) Survival after BMT. (B) Leukemia mortality in chimeras injected with EL4 cells ( $n=6-9 /$ group). Data from a representative experiment of 2 similar experiments are shown. Mean \pm SEM numbers of donor CD8+ T cells in spleens ( $n=3-6 /$ group) (C) and CTL activity against EL4 (D). ${ }^{*} P<0.05$ compared with allogeneic controls.
These results confirm that alloantigen expression on host epithelium induces apoptosis and dysfunction of alloreactive T cells, which results in impaired GVL effects.

Alloantigen expression on host non-hematopoietic cells stimulates programmed death-1 and its ligand pathway. Programmed death-1 (PD-1) is a negative regulator of activated $T$ cells and regulates $T$ cell exhaustion during chronic infections (18-20). PD-1 interacts with at least 2 ligands: PD ligand-1 (PD-L1) and PD-L2 (21). In particular, the PD-1/PD-L1 pathway has been proposed as one of the most important mechanisms of $\mathrm{T}$ cell exhaustion and tolerance induction against infectious agents and tumors (19, 22-25). We therefore hypothesized that the PD-1/PD-L1 pathway plays a role in the loss of GVL effects in [B6 $\rightarrow$ B6] mice. To test this hypothesis, we examined PD-1 expression on donor $\mathrm{CD}^{+} \mathrm{T}$ cells in lymph nodes on day +14 and +21 after BMT. It was significantly upregulated in allogeneic $[\mathrm{B} 6 \rightarrow \mathrm{B} 6]$ recipients as compared with syngeneic controls but was low in $[\mathrm{B} 6 \rightarrow \mathrm{C} 3]$ mice (Figure $4, \mathrm{~A}$ and $\mathrm{B}$ ). We also investigated the expression of another inhibitory receptor, CTLA-4, on donor $\mathrm{CD}^{+} \mathrm{T}$ cells. Although the expression of cytoplasmic CTLA-4 was slightly upregulated in allogeneic animals as compared with syngeneic animals, its level did not differ between [B6 $\rightarrow \mathrm{B} 6]$ and [B6 $\rightarrow \mathrm{C} 3]$ mice $(5.5 \% \pm 1.0 \%$ vs. $4.5 \% \pm 0.2 \%$, respectively; $P=0.50)$.

We next examined PD-L1 expression in the liver by real-time PCR after BMT. PD-L1 expression was markedly upregulated in the liver of allogeneic controls as compared with syngeneic controls (Figure $4 \mathrm{C})$. In allogeneic $[\mathrm{B} 6 \rightarrow \mathrm{C} 3]$ mice, it was slightly upregulated on day +14 but not on day +21 . Immunohistochemical analysis confirmed upregulated expression of PD-L1 in the liver of [B6 $\rightarrow \mathrm{B} 6]$ mice, as previously reported (Figure 4D) $(21,26)$. These results showed that alloantigen expression on GVHD target epithelium is associated with upregulation of the PD-1/PD-L1 interactions between donor T cells and GVHD target tissue.

Blockade of the interaction between PD-1 and PD-L1 enhances GVL activity. We next examined whether blocking the PD-1/PD-L1 pathway could enhance GVL activity. [B6 $\rightarrow$ C3] and $[\mathrm{B} 6 \rightarrow \mathrm{B} 6$ ] chimeras were reirradiated and injected with TCD BM cells and $\mathrm{CD}^{+} \mathrm{T}$ cells from C3 donors. Mice were i.p. injected with $500 \mu \mathrm{g}$ of anti-PD-L1 mAb on day 0 and then with $200 \mu \mathrm{g}$ on days +3 , $+6,+9,+12,+15$, and +18 after BMT. In $[\mathrm{B} 6 \rightarrow \mathrm{B} 6]$ recipients, injection of anti-PD-L1 mAbs significantly restored $\mathrm{T}$ cell functions on day +14 , as assessed by CD69 expression (Figure 5A), IFN- $\gamma$ production (Figure 5B), and CTL activity (Figure 5C). In [B6 $\rightarrow$ C3] mice, it marginally upregulated CD69 expression, IFN- $\gamma$ production, and CTL activity, although differences were not statistically significant (Figure 5, A, B, and D). As a consequence, anti-PD-L1 $\mathrm{mAb}$ administration significantly increased the severity of GVHD in $[\mathrm{B} 6 \rightarrow \mathrm{B} 6]$ mice (Figure $5 \mathrm{E}$ ) but not in $[\mathrm{B} 6 \rightarrow \mathrm{C} 3]$ mice (Figure $5 F)$. PD-L1 blockade also significantly augmented GVL activity in $[\mathrm{B} 6 \rightarrow \mathrm{B} 6]$ recipients injected with EL4 cells on day 0 (Figure 5G, $P<0.05)$. It also delayed leukemia death in [B6 $\rightarrow$ C3] mice, although the difference was not statistically significant (Figure $5 \mathrm{H}, P=0.38)$. In controls, PD-L1 blockade did not affect leukemia mortality in TCD-BMT recipients (Figure $5 \mathrm{H}$ ) or $[\mathrm{B} 6 \rightarrow \mathrm{B} 6]$ recipients of syngeneic B6 CD8 ${ }^{+} \mathrm{T}$ cells (data not shown).

\section{Discussion}

Alloantigens are expressed in three major sites in HSCT recipients: APCs, GVHD target epithelium, and leukemia cells. Alloantigen expression on APCs is essential for the induction of GVHD (6), and an optimal GVL response occurs when alloantigens are expressed on both host APCs and tumor cells (7). Alloantigen expression on the epithelium is also critical for the induction of GVHD across mHA disparities (10), but GVHD can occur in the absence of alloantigen expression on epithelium in MHC-mismatched BMT (9). In this study, we addressed the effect of alloantigen expression on target epithelium in GVL using chimeric mouse models of GVHD and GVL across mHA disparities. Our models mimic clinical BMT in patients not in remission, since most of the mice relapsed after allogeneic BMT. This high tumor burden enabled us to compare the magnitude of GVL activity in our models, and we made sur- 


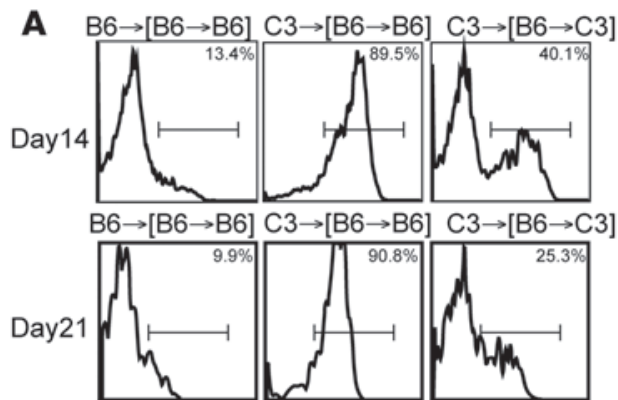

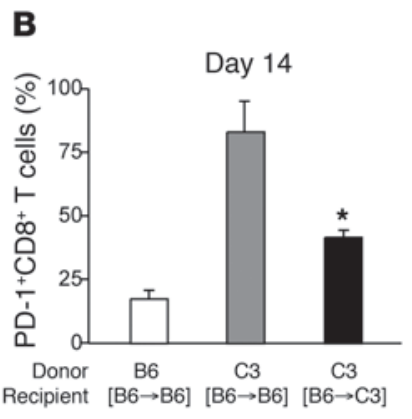

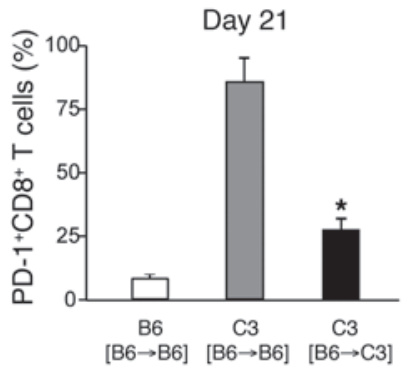

C

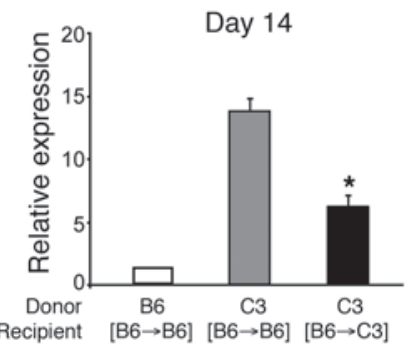

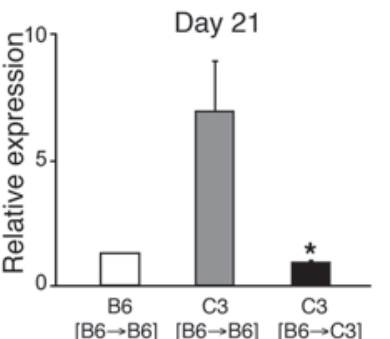

D $\quad \stackrel{\text { Day } 14}{\mathrm{~B} 6 \rightarrow[\mathrm{B} 6 \rightarrow \mathrm{B} 6]}$
Day 14

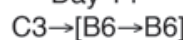

Day 14

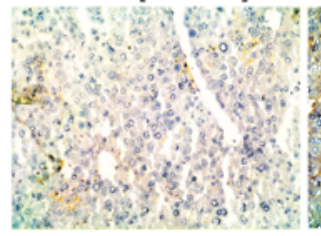

Day 21

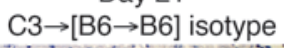

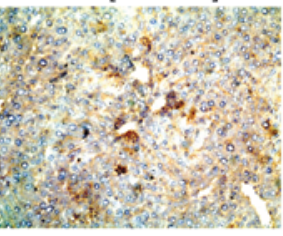

Day 21 $\mathrm{C} 3 \rightarrow[\mathrm{B} 6 \rightarrow \mathrm{C} 3]$

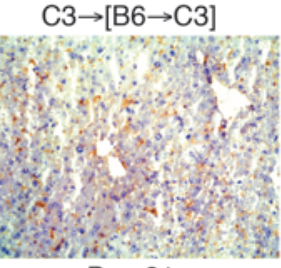

Day 21

$\mathrm{C} 3 \rightarrow[\mathrm{B} 6 \rightarrow \mathrm{C} 3]$

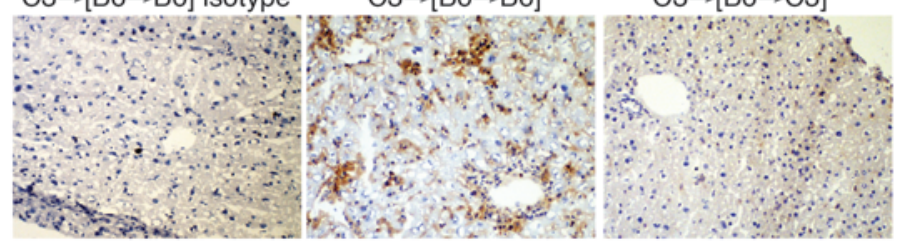

\section{Figure 4}

Alloantigen expression on host non-hematopoietic cells stimulates PD-1 and its ligand pathway. [B6 $\rightarrow$ B6] and [B6 $\rightarrow$ C3] chimeras were transplanted as indicated in the legend for Figure $1(n=4-8)$. (A) Representative histogram of PD-1 expression among donor CD8 ${ }^{+} \mathrm{T}$ cells on day +14 and +21 in syngeneic (left), allogeneic [B6 $\rightarrow$ B6] (middle), and [B6 $\rightarrow$ C3] (right) recipients. (B) Frequencies of PD-1+CD8 ${ }^{+} \mathrm{T}$ cells $(\mathrm{mean} \pm \mathrm{SD}$ ). (C) Relative expressions of Pdl1 mRNA on day +14 and +21 in the livers of allogeneic [B6 $\rightarrow$ B6] (gray bars) and allogeneic [B6 $\rightarrow$ C3] mice (black bars). Data represent the mean $( \pm \mathrm{SD}$ ) of $n$-fold difference in the amount of $P$ dl1 gene expression relative to that in syngeneic mice. (D) PD-L1 expression in the liver on day +14 (top row) and +21 (bottom row) from syngeneic (upper left) and allogeneic [B6 $\rightarrow B 6]$ (middle) and [B6 $\rightarrow$ C3] (right) recipients. Isotype control of allogeneic [B6 $\rightarrow \mathrm{B} 6]$ (lower left) is shown. Original magnification, $\times 200 .{ }^{*} P<0.05$ compared with allogeneic controls.

prising observations that alloantigen expression on non-hematopoietic cells inhibited GVL effects but enhanced GVHD. This observation challenges the current paradigm that GVL activity is strongly correlated with the severity of $\operatorname{GVHD}(1,2,27)$.

We found that alloantigen expression on non-hematopoietic cells induced donor $\mathrm{T}$ cell apoptosis and led to a contraction in the size of an alloreactive donor $\mathrm{CD}^{+} \mathrm{T}$ cell pool early after BMT. The remainder of the donor $T$ cells were alive, but their ability to produce cytokines and cytotoxicity were impaired. This defect is similar to $T$ cell exhaustion, which is a principal reason for the inability of the host to eliminate the persisting pathogen in chronic infections $(18,28) . \mathrm{CD}^{+} \mathrm{T}$ cell proliferation and differentiation into cytolytic effectors on an encounter with antigens are variable and change as a consequence of the antigen load (29). As the magnitude of the viral load increases, virus-specific $\mathrm{T}$ cells become more functionally impaired. During persistent infection, a high antigen load drives a significant number of virus-specific $T$ cells into activation-induced apoptosis, and the remaining virus-specific $\mathrm{T}$ cells remain alive but in a dysfunctional state of cytotoxicity (18, 30-33). In tumor models, antigen quantity determines the behavior of the $\mathrm{CD}^{+}$effector cells, including their effector function and sensitivity to apoptosis (34-36). In patients with a larger tumor burden, $\mathrm{CD}^{+} \mathrm{T}$ cells were found to undergo apoptosis (37). Thus, a higher alloantigen load in allogeneic controls as compared with chimeras, in which alloantigen expression is limited to hematopoietic cells and tumor cells, may induce apoptosis and the dysfunction of alloreactive $\mathrm{T}$ cells, which leads to the inability of the host to eliminate leukemia.

Our results are consistent with seminal observations by Meunier, Fontaine, and colleagues, who showed that the adoptive transfer of immunodominant mHA (B6 $\left.6^{\text {dom } 1}\right)$-specific $\mathrm{T}$ cells eradicates $\mathrm{B} 6^{\mathrm{dom} 1}$-expressing leukemia more efficiently in mice lacking $\mathrm{B} 6^{\mathrm{dom} 1}$ expression than in mice expressing B $6^{\text {dom } 1}$ (38). This was because the widespread expression of $\mathrm{B} 6^{\mathrm{dom} 1}$ caused activation-induced apoptosis and dysfunction of donor $\mathrm{T}$ cells in mice expressing $\mathrm{B}^{\mathrm{dom} 1}(38,39)$. These findings along with our results indicate that allogeneic cellular therapy targeting mHAs exclusively expressed on APCs and tumor cells can induce a potent GVL effect while inducing less-severe GVHD than immunotherapy via targeting of ubiquitously expressed mHAs (40).

The PD-1/PD-L1 pathway is critically involved in T cell exhaustion and tolerance induction in infection and tumor immunology $(18-20,23-25,41)$. It is also required for protection against chronic rejection of cardiac allograft, and induction of peripheral dele- 
A

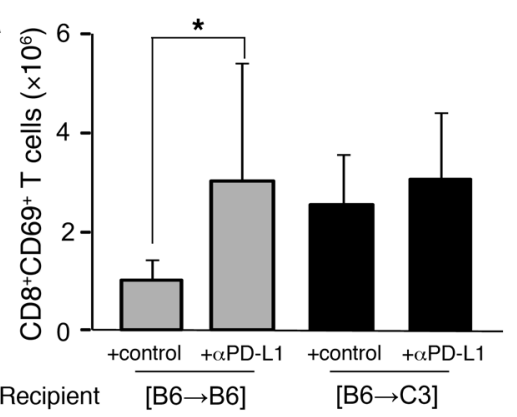

D

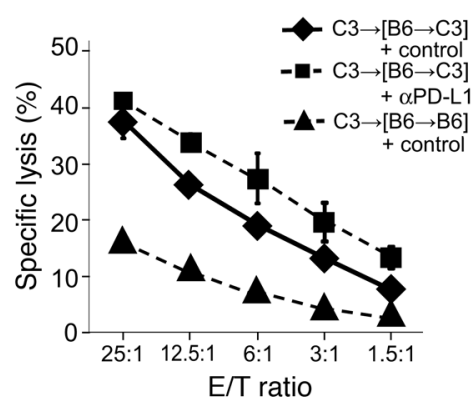

B

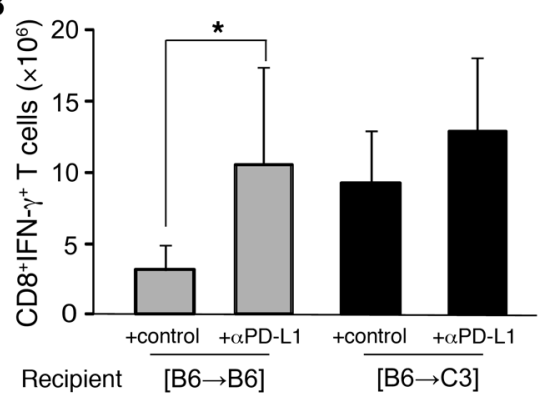

E

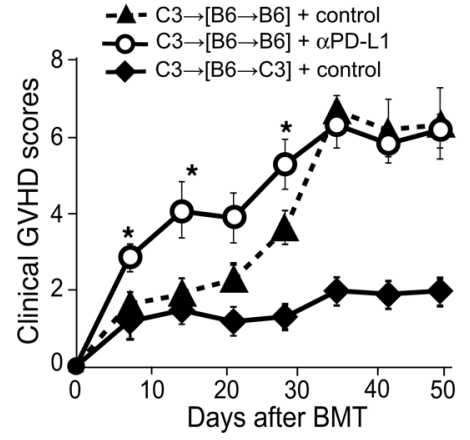

C

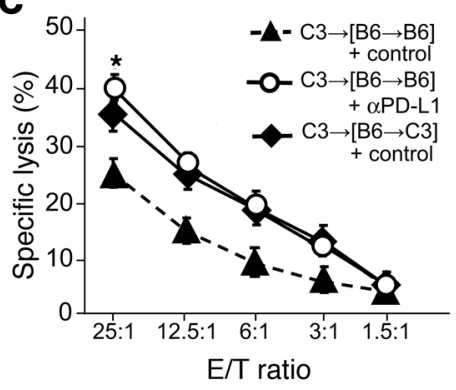

$\mathbf{F}$

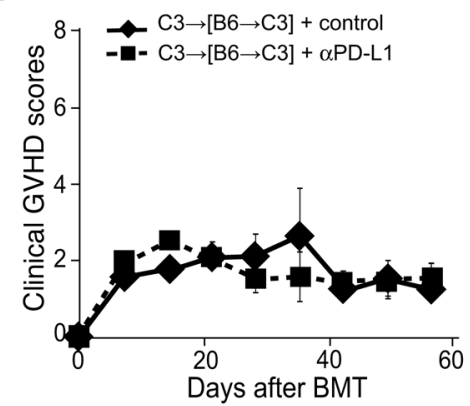

G

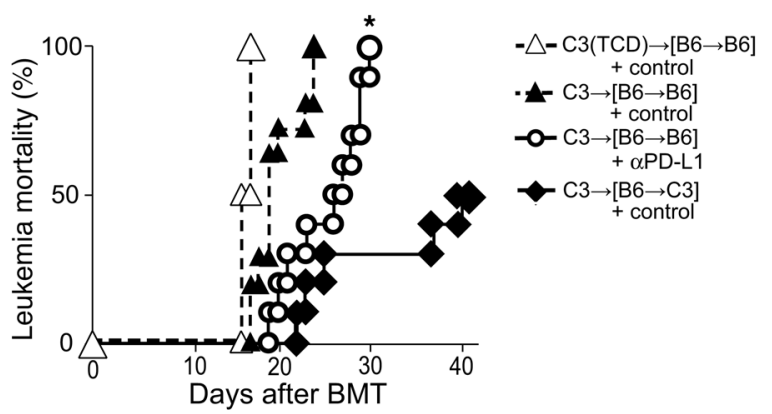

H

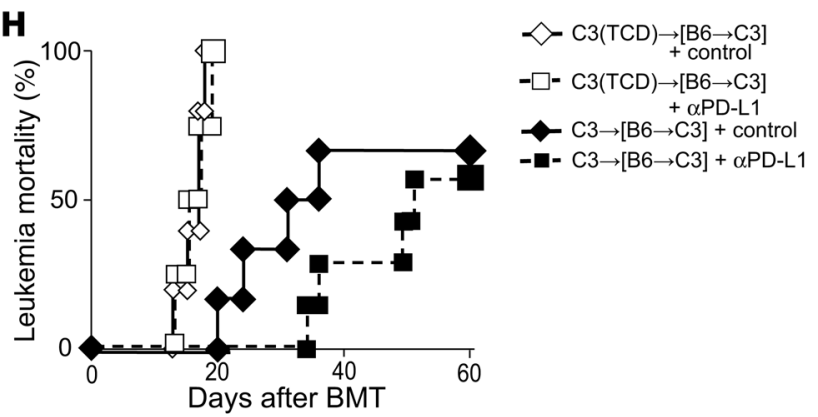

Figure 5

Blockade of the interaction between PD-1 and PD-L1 enhances GVL activity. [B6 $\rightarrow \mathrm{C} 3]$ and $[\mathrm{B} 6 \rightarrow \mathrm{B} 6]$ chimeras were reirradiated and injected with $5 \times 10^{6}$ TCD BM cells alone or with $1 \times 10^{6} \mathrm{CD}^{+} \mathrm{T}$ cells from C3 donors. Mice were i.p. injected with $500 \mu \mathrm{g}$ of anti PD-L1 mAbs or controls on day 0 and then $200 \mu \mathrm{g}$ thereafter on days $+3,+6,+9,+12,+15$, and +18 . Splenocytes were harvested on day +14 to determine the number of CD8+CD69+ T cells $(\mathbf{A})$ and IFN- $\gamma$-producing CD8+ T cells (B) and CTL activity against EL4 targets (C and D). Results from a representative experiment of 2 similar experiments (means $\pm \mathrm{SD}, n=7-8 /$ group). Mean clinical GVHD scores $( \pm \mathrm{SEM})(\mathrm{E}$ and $\mathbf{F})$ after BMT are shown ( $n=5-7$ /group). ( $\mathbf{G}$ and $\mathbf{H}$ ) Leukemia mortality after BMT in [B6 $\rightarrow$ B6] and [B6 $\rightarrow$ C3] chimeras injected with EL4 cells on day 0 ( $n=4-11 / g r o u p)$. Data from two similar experiments were combined. $\alpha$ PD-L1, anti-PD-L1 mAbs. ${ }^{*} P<0.05$ compared with the corresponding controls.

tional tolerance of alloreactive, anti-donor $\mathrm{CD}^{+} \mathrm{T}$ cells to achieve successful engraftment in BMT $(42,43)$. In this study, we found that PD-1 expression was upregulated in donor T cells and PD-L1 expression was upregulated in GVHD target organs. The expression of PD-1/PD-L1 was markedly reduced in chimeras lacking alloantigen expression on non-hematopoietic cells. PD-1 and PD-L1 expression is induced upon cell activation and inflammation in GVHD (44); therefore, the absence of alloantigen expression on GVHD target epithelium reduced GVHD in chimeric mice, which resulted in insufficient stimulation of the PD-1/PD-L1 interaction. Target tissue expression of PD-L1 is also critical for the induction of $\mathrm{T}$ cell exhaustion or tolerance in chronic viral infection, autoimmune diabetes, and cardiac allografting $(19,42,45)$.

Both PD-1 and PD-L1 were markedly upregulated in [B6 $\rightarrow \mathrm{B} 6]$ mice, but they were also modestly upregulated in $[\mathrm{B} 6 \rightarrow \mathrm{C} 3]$ mice. Blockade of PD-1/PD-L1 interactions significantly restored $\mathrm{T}$ cell effector functions in $[\mathrm{B} 6 \rightarrow \mathrm{B} 6]$ mice but modestly restored them in $[\mathrm{B} 6 \rightarrow \mathrm{C} 3]$ mice as well. The relevance of these observations is shown by the PD-1/PD-L1 blockade studies. These data showed that the PD-1/PD-L1 pathway is particularly germane to $[\mathrm{B} 6 \rightarrow \mathrm{B} 6]$ mice with widespread expression of alloantigens but also applies, at least in part, to [B6 $\rightarrow \mathrm{C} 3]$ mice, wherein alloantigen expression is only on APCs. While there is likely to be a role for this pathway in the absence of epithelial alloantigen expression, the full negative impact of this pathway on GVL is only seen when alloantigen expression is present on non-hematopoietic tissues.

Of note, the improvement in GVL by the PD-1/PD-L1 blockade was partial, as has been shown in chronic viral infection (46-48). This may be due to the presence of multiple negative regulatory pathways that contribute to $T$ cell exhaustion, including CTLA-4, IL-10, LAG-3, CD160, and 2B4 $(20,47,49)$. In addition, the population of exhausted $\mathrm{T}$ cells is heterogeneous, and this interven- 
tion is effective only for PD- $1^{\text {lo }}$ and not PD- $1^{\text {hi }}$, which are subsets of exhausted T cells (50). Many of these inhibitory receptors are either coexpressed by the same exhausted $\mathrm{T}$ cells or differentially expressed on different subsets of exhausted cells. As the severity of the infection increases, the number of different inhibitors expressed per cell increases (47). A second inhibitory receptor, CTLA-4, can be overexpressed by exhausted $\mathrm{CD}^{+} \mathrm{T}$ cells in chronic viral infection, but it appears to have a minimal role on exhausted CD8 ${ }^{+}$ T cells $(19,51)$. Although CTLA-4 was only slightly upregulated on $\mathrm{CD}^{+} \mathrm{T}$ cells in contrast to the marked upregulation of PD-1 in our CD8-dependent model of MHC-matched BMT, the precise inhibitory receptors of therapeutic interest may differ between $\mathrm{CD}^{+}$-dependent and CD8 ${ }^{+}$-dependent GVHD/GVL. Another key negative regulatory pathway is mediated by Foxp $3^{+}$Tregs. However, enhancement of GVL is not due to effects of the PD-1/PD-L1 blockade on Tregs, because blockade of PD-1/PD-L1 interactions enhances the expansion and function of Tregs (52). The hierarchy of these pathways in regulating GVL will need to be studied in the future based on better understanding of the delineation of $\mathrm{T}$ cell subsets and models (53). However, our results suggest the detrimental effect of GVHD-induced immunosuppression on GVL responses, regardless of which inhibitory pathway might be dominant clinically.

In addition, the administration of anti-PD-L1 mAb also exacerbated acute GVHD, as has been shown in a previous study (54). Therefore, the beneficial effects of the PD-1/PD-L1 blockade may be offset by the exacerbation of GVHD. Effects of the inhibitory receptor blockade might depend on the magnitude or stage of donor $\mathrm{T}$ cell activation and the severity of GVHD; therefore, the timing and duration of the targeting may be important.

In clinical HSCT, alloantigens continue to be presented on MHC class I in non-hematopoietic cells throughout the lifetime of the transplant recipients. However, a substantial number of patients eventually develop tolerance after resolution of GVHD and often experience leukemia relapse. Although activation-induced apoptosis of alloreactive $\mathrm{T}$ cells has been proposed as an explanation of this paradox (55), studies monitoring GVHD-specific T cell clones indicate that host-reactive $\mathrm{T}$ cells are continuously present after allogeneic HSCT (56-58). Our results provide a logical explanation for this paradox. However, the process of exhaustion is unlikely to occur in patients not developing GVHD, because induction of $T$ cell exhaustion requires antigen-specific activation of $T$ cells and subsequent differentiation into effector $\mathrm{T}$ cells. In these patients, tolerance could be induced by other mechanisms, such as functional central and peripheral tolerance mechanisms. It is well known that GVL is not apparent in patients with high leukemia burden. Although leukemia cells used in the current study do not express PD-L1 $(22,59)$, leukemia cells expressing PD-L1 may also directly limit the GVL response in patients with high leukemia burden $(22,24,25)$. However, such insights from animal models must be extrapolated with caution to clinical studies involving humans.

It has been assumed that $\mathrm{T}$ cell exhaustion is antigen specific in chronic viral infection. Bystander lysis of T cells has also been reported in the course of viral infections (60), but is of minimal significance because of its limited magnitude and because normal thymic function can replenish the peripheral $\mathrm{T}$ cell pool. In contrast, in GVHD, $\mathrm{T}$ cell exhaustion occurs after initial $\mathrm{T}$ cell activation and the subsequent development of GVHD. GVHD induces bystander apoptosis of non-host-reactive T cells. In addition, GVHD-mediated injury of the thymus and the secondary lymphoid organs inhibits full replenishment of the peripheral $\mathrm{T}$ cell pool (55). Thus, establishment of full immune competence probably requires the additional process of $\mathrm{T}$ cell reconstitution following $\mathrm{T}$ cell exhaustion.

In conclusion, our results indicated the significance of alloantigen expression on non-hematopoietic cells in GVL. Alloantigen expression on non-hematopoietic cells induces the apoptosis of donor $T$ cells and the dysfunction of cytotoxic effector function, which leads to a reduction in GVL activity. T cell dysfunction was partially restored by blocking PD-1/PD-L1 interactions, which suggests that the therapeutic "tuning" of T cell responses via modulation of negative regulatory pathways represents a novel strategy for enhancing GVL. Our results in combination with those of previous studies $(6,7,9,10,38,39)$ provide a complete picture of the effect of alloantigen expression on host APCs, GVHD target epithelium, and tumor cells in allogeneic HSCT; alloantigen expression on host non-hematopoietic cells augments GVHD but suppresses GVL effects. This concept may provide an important framework for understanding the pathophysiology of GVHD and allow for the separation of GVHD and GVL.

\section{Methods}

Mice. Female C57BL/6 (B6, H-2 $\left.{ }^{\mathrm{b}}, \mathrm{CD} 45.2^{+}\right)$, BALB/c (Ba, H-2 $)$, and DBA/2 $\left(\mathrm{Db}, \mathrm{H}-2^{\mathrm{d}}\right)$ mice were purchased from Charles River Japan. B6.Ly5.1 (H-2 ${ }^{\mathrm{b}}$, $\left.\mathrm{CD} 45.1^{+}\right)$and $\mathrm{C} 3 \mathrm{H} . \mathrm{Sw}\left(\mathrm{C} 3, \mathrm{H}-2^{\mathrm{b}}\right)$ mice were purchased from The Jackson Laboratory. B6-background $\beta_{2}$ m-deficient mice $\left(\beta_{2} \mathrm{~m}^{-/-}\right.$: B6.129- $\beta_{2^{-}}$ $\left.\mathrm{m}^{\text {tmIIae }} \mathrm{N} 12\right)$ were purchased from Taconic. The age of mice used ranged from 8 to 12 weeks. Mice were maintained in specific pathogen-free conditions and received normal chaw and hyperchlorinated drinking water for the first 3 weeks after BMT. All experiments involving animals were performed according to a protocol approved by the Institutional Animal Care and Research Advisory Committee of Okayama University and Kyushu University.

Generation of bone marrow chimera and induction of GVHD and GVL. Total body irradiation (TBI: X-ray) was split into 2 doses separated by 4 hours to minimize gastrointestinal toxicity. B6 and C3 mice received 10 Gy TBI, whereas $\mathrm{Ba}$ and $\mathrm{Db}$ mice received 8.5 Gy TBI. To create BM chimeras, lethally irradiated mice were intravenously injected with $5 \times 10^{6} \mathrm{TCD}$ BM cells from donors. TCD was performed using anti-CD90 microbeads and AutoMACS (Miltenyi Biotec). Four months later, the chimeric mice were reirradiated and injected with $5 \times 10^{6} \mathrm{TCD}$ BM cells plus various doses of $\mathrm{CD}^{+} \mathrm{T}$ cells or $2 \times 10^{6} \mathrm{~T}$ cells. T cells and $\mathrm{CD}^{+} \mathrm{T}$ cells were negatively isolated from splenocytes by using a $\mathrm{T}$ cell isolation kit and a $\mathrm{CD} 8^{+} \mathrm{T}$ cell isolation kit (Miltenyi Biotec), respectively, and the AutoMACS. In the GVL experiments, EL4 $\left(\mathrm{H}-2^{\mathrm{b}}\right)$ derived from a B6 mouse, P815 $\left(\mathrm{H}-2^{\mathrm{d}}\right)$ derived from a Db mouse, and A20 $\left(\mathrm{H}-2^{\mathrm{d}}\right)$ derived from a Ba mouse were intravenously injected into BMT recipients on day 0 of BMT. Anti-PD-L1 mAbs were purified from the hybridoma supernatant of clone MIH5 (61), which was a gift from Miyuki Azuma of Tokyo Medical and Dental University, Tokyo, Japan, and i.p. injected at a dose of $500 \mu \mathrm{g} / \mathrm{mouse}$ on day 0 , followed by $200 \mu \mathrm{g} /$ mouse on days $+3,+6,+9,+12,+15$, and +18 after BMT.

Assessment of GVHD and GVL effects. Survival after BMT was monitored daily, and the degree of clinical GVHD was assessed weekly by using a scoring system that sums changes in 5 clinical parameters: weight loss, posture, activity, fur texture, and skin integrity (maximum index, 10) as described previously (13). The cause of each death after BMT was determined by post mortem examination, and was either GVHD or tumor. The most striking leukemiaspecific abnormality induced by EL4, P815, and A20 was macroscopic tumor nodules, marked hepatosplenomegaly, and lower limb paralysis (62). Leukemia death induced by EL4, P815, and A20 was therefore defined by the occurrence of hepatosplenomegaly, macroscopic tumor nodules in the liver 
and/or spleen, or hind leg paralysis. GVHD death was defined as the absence of leukemia and by the presence of clinical signs of GVHD, assessed by using a clinical scoring system. Animals surviving beyond the observation period of BMT were sacrificed, and the spleen and liver were harvested for histological evaluation to determine leukemia-free survival.

Flow cytometric analysis. The mAbs used were FITC-, PE-, PerCP-, Cy5.5-, or APC-conjugated anti-mouse CD5.1, CD8, CD45.1, CD45.2, CD69, and PD-1 (BD Biosciences). Cells positive for 7-amino-actinomycin D (BD Biosciences) were excluded from the analysis. For the analysis of donor $\mathrm{T}$ cell apoptosis, the cells were stained with Annexin V (MBL). For intracellular IFN- $\gamma$ staining, the splenocytes were incubated for 4 hours with leukocyte activation cocktail and BD GolgiPlug (BD Biosciences) at $37^{\circ} \mathrm{C}$. Then, the cells underwent permeabilization with a BD Cytofix/Cytoperm solution (BD Biosciences) and were stained with FITC-conjugated anti-IFN- $\gamma$ mAbs (BD Biosciences). For intracellular CTLA-4 staining, cells were stained with PE-conjugated antiCTLA-4 mAbs (eBioscience). At least 5,000 live events were acquired for the analysis using a FACSCalibur flow cytometer (BD Biosciences).

CTL assay. Splenocytes were removed from chimeric recipients 14 days after BMT, and the mononuclear cells were then separated by density gradient centrifugation. The percentage of $\mathrm{CD}^{+}$cells in this fraction was determined by flow cytometry, and counts were normalized for $\mathrm{CD} 8^{+}$cell numbers. Tumor targets, $2 \times 10^{6} \mathrm{P} 815$ or EL4, were labeled with $100 \mu \mathrm{Ci}$ of ${ }^{51} \mathrm{Cr}$ sodium salt (Amersham Biosciences) for 2 hours. After washing 3 times, the labeled targets were resuspended in 10\% FCS in RPMI and plated at $10^{4}$ cells per well in U-bottom plates (Corning-Costar Corp.). Allogeneic splenocyte preparations, as described above, were added to quadruplicate wells at varying effector-to-target ratios and incubated for 4 hours. Maximal and background release were determined by adding $1 \%$ SDS and media alone to the targets, respectively. ${ }^{51} \mathrm{Cr}$ activity in the supernatants collected 4 hours later was determined using a Wallac 1470 WIZARD Gamma Counter (Wallac Oy), and lysis was expressed as a percentage of maximum: percentage of specific lysis $=100$ (sample count - background count $/$ maximum count - background count).

Quantitative real-time PCR. Total RNA was isolated from the frozen liver using ISOGEN (Nippon Gene). cDNA was synthesized from $150 \mu \mathrm{g}$ RNA using a QuantiTect Reverse Transcription Kit (QIAGEN). Pdl1 mRNA levels were quantified by real-time PCR using the 7500 Real-Time PCR System (Applied Biosystems). TaqMan Universal PCR MasterMix, primers, and the fluorescent TaqMan probe specific for murine PD-L1 (Mm00452054-m1) and a house keeping gene, mGAPDH (Mm99999915-g1), were purchased from Applied Biosystems. The standard was obtained using RNA extracted from syngeneic controls.

Immunohistochemistry. For immunohistochemical analysis, isolated livers were frozen in Tissue-Tek (Sakura Finetek), and 5- $\mu \mathrm{m}$ cryostat sections were prepared. Slides were fixed in $100 \%$ acetone and air dried. Endogenous peroxidase activity was blocked with peroxidase blocking reagent (Dako). The sections were incubated with purified rat anti-mouse PD-L1 mAb (clone MIH5; eBiosciences). The primary Abs were detected using the Histofine Simple Stain Mouse MAX PO (Rat) kit and DAB solution (Nichirei). The images were captured using an Olympus BH2 microscope with a Nikon DS$5 \mathrm{M}$ color digital camera (Nikon), controlled by Nikon ATC-2U software version 1.5. An Olympus $\times 10 / 20$ ocular lens and a $\times 20 / 0.46$ NA objective lens were used. Images were cropped using Adobe Photoshop (Adobe Systems) and were composed using Adobe Illustrator.

Statistics. We used the Kaplan-Meier product-limit method to obtain survival probability and the log-rank test to compare survival curves. The Mann-Whitney $U$ test was used to analyze the clinical scores. A $P$ value less than 0.05 was considered statistically significant.

\section{Acknowledgments}

We thank Miyuki Azuma of Tokyo Medical and Dental University for providing hybridoma MIH5-producing anti-PD-L1 mAbs. This study was supported by grant 21390295 from the Ministry of Education, Culture, Sports, Science, and Technology (Tokyo, Japan) (to T. Teshima), Health and Labor Science Research Grants (Tokyo, Japan) (to T. Teshima), and a grant from the Foundation for Promotion of Cancer Research (Tokyo, Japan) (to T. Teshima).

Received for publication March 11, 2009, and accepted in revised form April 7, 2010.

Address correspondence to: Takanori Teshima, Center for Cellular and Molecular Medicine, Kyushu University Hospital, 3-1-1 Maidashi, Higashi-ku, Fukuoka 812-8582, Japan. Phone: 81.92.642.5947; Fax: 81.92.642.5951; E-mail: tteshima@cancer. med.kyushu-u.ac.jp.
1. Weiden $P$, et al. Antileukemic effect of graft-versushost disease in human recipients of allogeneic-marrow grafts. NEnglJ Med. 1979;300(19):1068-1073.

2. Weiden PL, Sullivan KM, Flournoy N, Storb R, Thomas ED. Antileukemic effect of chronic graftversus-host disease: contribution to improved survival after allogeneic marrow transplantation. NEngl J Med. 1981;304(25):1529-1533.

3. Korngold R, Sprent J. Lethal graft-versus-host disease after bone marrow transplantation across minor histocompatibility barriers in mice. Prevention by removing mature T-cells from marrow. J Exp Med. 1978;148(6):1687-1698.

4. Apperley JF, Jones L, Hale G, Goldman JM. Bone marrow transplantation for chronic myeloid leukemia: T-cell depletion with Campath-1 reduces the incidence of acute graft-versus-host disease but may increase the risk of leukemia relapse. Bone Marrow Transplant. 1986;1(1):53-66.

5. Atkinson K, et al. Risk factors for chronic graft-versushost disease after HLA-identical sibling bone marrow transplantation. Blood. 1990;75(12):2459-2464.

6. Shlomchik WD, et al. Prevention of graft versus host disease by inactivation of host antigen-presenting cells. Science. 1999;285(5426):412-415.

7. Reddy P, Maeda Y, Liu C, Krijanovski OI, Korngold R, Ferrara JL. A crucial role for antigen-presenting cells and alloantigen expression in graft-versus-leukemia responses. Nat Med. 2005;11(11):1244-1249.

8. Bleakley M, Riddell SR. Molecules and mechanisms of the graft-versus-leukaemia effect. Nat Rev Cancer. 2004;4(5):371-380.

9. Teshima $\mathrm{T}$, et al. Acute graft-versus-host disease does not require alloantigen expression on host epithelium. Nat Med. 2002;8(6):575-581.

10. Jones SC, Murphy GF, Friedman TM, Korngold R. Importance of minor histocompatibility antigen expression by nonhematopoietic tissues in a CD4+ $\mathrm{T}$ cell-mediated graft-versus-host disease model. J Clin Invest. 2003;112(12):1880-1886.

11. Ruggeri L, et al. Effectiveness of donor natural killer cell alloreactivity in mismatched hematopoietic transplants. Science. 2002;295(5562):2097-2100.

12. Matte CC, et al. Donor APCs are required for maximal GVHD but not for GVL. Nat Med. 2004; 10(9):987-992.

13. Cooke KR, et al. An experimental model of idiopathic pneumonia syndrome after bone marrow transplantation. I. The roles of minor $\mathrm{H}$ antigens and endotoxin. Blood. 1996;88(8):3230-3239.

14. Korngold R, Sprent J. Features of T cells causing H-2-restricted lethal graft-vs.-host disease across minor histocompatibility barriers. J Exp Med. 1982;155(3):872-883.
15. Zhang Y, Joe G, Hexner E, Zhu J, Emerson SG. Alloreactive memory $T$ cells are responsible for the persistence of graft-versus-host disease. J Immunol. 2005;174(5):3051-3058.

16. Stefanova I, Dorfman JR, Germain RN. Self-recognition promotes the foreign antigen sensitivity of naive T lymphocytes. Nature. 2002;420(6914):429-434.

17. Zhang Y, Louboutin JP, Zhu J, Rivera AJ, Emerson SG. Preterminal host dendritic cells in irradiated mice prime CD8+ T cell-mediated acute graft-versushost disease. J Clin Invest. 2002;109(10):1335-1344.

18. Zajac AJ, et al. Viral immune evasion due to persistence of activated $\mathrm{T}$ cells without effector function. J Exp Med. 1998;188(12):2205-2213.

19. Barber DL, et al. Restoring function in exhausted CD8 $\mathrm{T}$ cells during chronic viral infection. Nature. 2006; 439(7077):682-687.

20. Shin H, Wherry EJ. CD8 T cell dysfunction during chronic viral infection. Curr Opin Immunol. 2007; 19(4):408-415.

21. Keir ME, Butte MJ, Freeman GJ, Sharpe AH. PD-1 and its ligands in tolerance and immunity. Annu Rev Immunol. 2008;26:677-704.

22. Dong H, et al. Tumor-associated B7-H1 promotes T-cell apoptosis: a potential mechanism of immune evasion. Nat Med. 2002;8(8):793-800.

23. Ahmadzadeh $M$, et al. Tumor antigen-specific CD8 
$T$ cells infiltrating the tumor express high levels of PD-1 and are functionally impaired. Blood. 2009; 114(8):1537-1544

24. Zhang L, Gajewski TF, Kline J. PD-1/PD-L1 interactions inhibit anti-tumor immune responses in a murine acute myeloid leukemia model. Blood. 2009; 114(8):1545-1552.

25. Mumprecht S, Schurch C, Schwaller J, Solenthaler $\mathrm{M}$, Ochsenbein $\mathrm{AF}$. PD-1 signaling on chronic myeloid leukemia-specific $\mathrm{T}$ cells results in $\mathrm{T}$ cell exhaustion and disease progression. Blood. 2009; 114(8):1528-1536

26. Iwai Y, Terawaki S, Ikegawa M, Okazaki T, Honjo T. PD-1 inhibits antiviral immunity at the effector phase in the liver. J Exp Med. 2003;198(1):39-50.

27. Horowitz MM, et al. Graft-versus-leukemia reactions after bone marrow transplantation. Blood. 1990;75(3):555-562.

28. Gallimore A, et al. Induction and exhaustion of lymphocytic choriomeningitis virus-specific cytotoxic T lymphocytes visualized using soluble tetrameric major histocompatibility complex class I-peptide complexes. J Exp Med. 1998;187(9):1383-1393.

29. Welsh RM. Assessing CD8 T cell number and dysfunction in the presence of antigen. J Exp Med. 2001; 193(5):F19-F22.

30. Moskophidis D, Lechner F, Pircher H, Zinkernagel RM. Virus persistence in acutely infected immunocompetent mice by exhaustion of antiviral cytotoxic effector T cells. Nature. 1993;362(6422):758-761.

31. Appay V, et al. HIV-specific CD8(+) T cells produce antiviral cytokines but are impaired in cytolytic function. J Exp Med. 2000;192(1):63-75.

32. Xiong Y, et al. Simian immunodeficiency virus (SIV) infection of a rhesus macaque induces SIV-specific CD8(+) T cells with a defect in effector function that is reversible on extended interleukin-2 incubation. J Virol. 2001;75(6):3028-3033.

33. Pantaleo G, Harari A. Functional signatures in antiviral T-cell immunity for monitoring virus-associated diseases. Nat Rev Immunol. 2006;6(5):417-423.

34. Tham EL, Mescher MF. Signaling alterations in activation-induced nonresponsive CD8 T cells. Immunol. 2001;167(4):2040-2048.

35. Tham EL, Shrikant P, Mescher MF. Activationinduced nonresponsiveness: a Th-dependent regulatory checkpoint in the CTL response. J Immunol. 2002;168(3):1190-1197.

36. Boissonnas A, et al. Antigen distribution drives programmed antitumor CD8 cell migration and determines its efficiency. J Immunol. 2004;173(1):222-229.
37. Saito T, Dworacki G, Gooding W, Lotze MT, Whiteside TL. Spontaneous apoptosis of CD8+ T lymphocytes in peripheral blood of patients with advanced melanoma. Clin Cancer Res. 2000;6(4):1351-1364.

38. Fontaine P, Roy-Proulx G, Knafo L, Baron C, Roy DC, Perreault C. Adoptive transfer of minor histocompatibility antigen-specific $\mathrm{T}$ lymphocytes eradicates leukemia cells without causing graftversus-host disease. Nat Med. 2001;7(7):789-794.

39. Meunier MC, Roy-Proulx G, Labrecque N, Perreault C. Tissue distribution of target antigen has a decisive influence on the outcome of adoptive cancer immunotherapy. Blood. 2003;101(2):766-770.

40. Dickinson AM, et al. In situ dissection of the graftversus-host activities of cytotoxic $T$ cells specific for minor histocompatibility antigens. Nat Med. 2002; 8(4):410-414.

41. Ding ZC, Blazar BR, Mellor AL, Munn DH, Zhou G. Chemotherapy rescues tumor-driven aberrant CD4+ T-cell differentiation and restores an activated polyfunctional helper phenotype. Blood. 2010; 115(12):2397-2406

42. Tanaka $\mathrm{K}$, et al. PDL1 is required for peripheral transplantation tolerance and protection from chronic allograft rejection. J Immunol. 2007; 179(8):5204-5210

43. Haspot F, et al. Peripheral deletional tolerance of alloreactive CD8 but not CD4 T cells is dependent on the PD-1/PD-L1 pathway. Blood. 2008; 112(5):2149-2155.

44. Yamazaki T, et al. Expression of programmed death 1 ligands by murine T cells and APC. J Immunol. 2002;169(10):5538-5545.

45. Keir ME, et al. Tissue expression of PD-L1 mediates peripheral T cell tolerance. J Exp Med. 2006; 203(4):883-895.

46. Crawford A, Wherry EJ. The diversity of costimulatory and inhibitory receptor pathways and the regulation of antiviral $\mathrm{T}$ cell responses. Curr Opin Immunol. 2009;21(2):179-186.

47. Blackburn SD, et al. Coregulation of CD8+ T cell exhaustion by multiple inhibitory receptors during chronic viral infection. Nat Immunol. 2009; 10(1):29-37.

48. Petrovas C, et al. PD-1 is a regulator of virus-specific CD8+ T cell survival in HIV infection. J Exp Med. 2006;203(10):2281-2292.

49. Brooks DG, Trifilo MJ, Edelmann KH, Teyton L, McGavern DB, Oldstone MB. Interleukin-10 determines viral clearance or persistence in vivo. Nat Med. 2006;12(11):1301-1309.
50. Blackburn SD, Shin H, Freeman GJ, Wherry EJ. Selective expansion of a subset of exhausted CD8 T cells by alphaPD-L1 blockade. Proc Natl Acad Sci US A. 2008;105(39):15016-15021.

51. Kaufmann DE, et al. Upregulation of CTLA-4 by HIV-specific CD4+ T cells correlates with disease progression and defines a reversible immune dysfunction. Nat Immunol. 2007;8(11):1246-1254.

52. Franceschini $\mathrm{D}$, et al. PD-L1 negatively regulates CD4+CD25+Foxp3+ Tregs by limiting STAT-5 phosphorylation in patients chronically infected with HCV. J Clin Invest. 2009;119(3):551-564.

53. Socie G, Blazar BR. Acute graft-versus-host disease: from the bench to the bedside. Blood. 2009; 114(20):4327-4336.

54. Blazar BR, et al. Blockade of programmed death-1 engagement accelerates graft-versus-host disease lethality by an IFN-gamma-dependent mechanism. J Immunol. 2003;171(3):1272-1277.

55. Brochu S, Rioux-Masse B, Roy J, Roy DC, Perreault C. Massive activation-induced cell death of alloreactive $\mathrm{T}$ cells with apoptosis of bystander postthymic $T$ cells prevents immune reconstitution in mice with graft-versus-host disease. Blood. 1999;94(2):390-400.

56 . Dey B, et al. The fate of donor T-cell receptor transgenic $\mathrm{T}$ cells with known host antigen specificity in a graft-versus-host disease model. Transplantation. 1999;68(1):141-149.

57. Choi EY, et al. Real-time T-cell profiling identifies $\mathrm{H} 60$ as a major minor histocompatibility antigen in murine graft-versus-host disease. Blood. 2002; 100(13):4259-4265.

58. Michalek J, Collins RH, Hill BJ, Brenchley JM, Douek DC. Identification and monitoring of graftversus-host specific T-cell clone in stem cell transplantation. Lancet. 2003;361(9364):1183-1185.

59. Hirano F, et al. Blockade of B7-H1 and PD-1 by monoclonal antibodies potentiates cancer therapeutic immunity. Cancer Res. 2005;65(3):1089-1096.

60. Ando K, et al. Perforin, Fas/Fas ligand, and TNFalpha pathways as specific and bystander killing mechanisms of hepatitis $C$ virus-specific human CTL. J Immunol. 1997;158(11):5283-5291.

61. Tsushima F, et al. Preferential contribution of B7$\mathrm{H} 1$ to programmed death-1-mediated regulation of hapten-specific allergic inflammatory responses. Eur I Immunol. 2003;33(10):2773-2782.

62. Teshima $T$, et al. IL-11 separates graft-versusleukemia effects from graft-versus-host disease after bone marrow transplantation. J Clin Invest. 1999;104(3):317-325. 